\title{
Attenuated $\mathrm{P}_{2} \mathrm{X}_{7}$ Pore Function as a Risk Factor for Virus-induced Loss of Asthma Control
}

\author{
Loren C. Denlinger ${ }^{1}$, Lei Shi ${ }^{1}$, Arturo Guadarrama ${ }^{1,2}$, Kathy Schell ${ }^{3}$, Dawn Green 4 , Alison Morrin ${ }^{5}$, Kirk Hogan 4 \\ Ronald L. Sorkness', William W. Busse ${ }^{1}$, and James E. Gern ${ }^{1,5}$ \\ ${ }^{1}$ Section of Allergy, Pulmonary, and Critical Care, Department of Medicine, ${ }^{2}$ Department of Biomolecular Chemistry, ${ }^{3}$ Paul P. Carbone \\ Comprehensive Cancer Center, ${ }^{4}$ Department of Anesthesiology, and ${ }^{5}$ Section of Allergy and Immunology, Department of Pediatrics, \\ University of Wisconsin, Madison, Wisconsin
}

\begin{abstract}
Rationale: Upper respiratory tract infection is a guideline accepted risk domain for the loss of asthma control. The ionotrophic nucleotide receptor $\mathrm{P} 2 \mathrm{X}_{7}$ regulates compartmentalized acute inflammation and the immune response to airway pathogens.

Objectives: We hypothesized that variability in $\mathrm{P}_{2} \mathrm{X}_{7}$ function contributes to neutrophilic airway inflammation during a cold and thereby is linked to acute asthma.

Methods: Research volunteers with asthma were enrolled at the onset of a naturally occurring cold and monitored through convalescence, assessing symptoms, lung function, and airway inflammation. $\mathrm{P}^{2} \mathrm{X}_{7}$ pore activity in whole blood samples was measured using a genomically validated flow cytometric assay.

Measurements and Main Results: Thirty-five participants with mild to moderate allergic asthma were enrolled and 31 completed all visits. $\mathrm{P}_{2} \mathrm{X}_{7}$ pore function correlated with the change in nasal lavage neutrophil counts during the cold $\left(R_{\mathrm{s}}=0.514, P=0.004\right)$ and was inversely related to the change in asthma symptoms $\left(R_{\mathrm{s}}=-0.486, P=\right.$ 0.009 ). The change in peak expiratory flow recordings, precold use of inhaled corticosteroids, and $\mathrm{P} 2 \mathrm{X}_{7}$ pore function were multivariate predictors of asthma symptoms $(P=0.001,<0.001$ and $=0.003$ respectively). Attenuated $\mathrm{P} 2 \mathrm{X}_{7}$ activity was associated with the risk of losing asthma control (crude odds ratio, 11.0; 95\% confidence interval, 1.1-106.4) even after adjustment for inhaled corticosteroids and rhinovirus (odds ratio, 15.0).

Conclusions: A whole blood $\mathrm{P}_{2} \mathrm{X}_{7}$ pore assay robustly identifies participants with loss-of-function genotypes. Using this assay as an epidemiologic tool, attenuated $\mathrm{P}_{2} \mathrm{X}_{7}$ pore activity may be a novel biomarker of virus-induced loss of asthma control.
\end{abstract}

Keywords: asthma; virus; neutrophils; $\mathrm{P}_{2} \mathrm{X}_{7}$

Approximately 50 to $85 \%$ of asthma exacerbations are attributed to respiratory viruses, and some of these airway pathogens appear to be involved in the inception of the disease (1-4). Although most viruses that infect the upper airway can cause exacerbations, rhinoviral exacerbations are considered to be the most frequent, can be among the most severe, and are often associated with airway neutrophilia $(1,2,5-9)$. The severity of the inflammatory response in the lower airway and attributable symptoms are highly variable $(6,10)$. It is likely that strain variation among rhinoviruses leads to differences in the intensity of the infection and the inflammatory response, with host factors as possible contributors (11-14). Accordingly, only a subset of colds leads to

(Received in original form February 18, 2008; accepted in final form November 20, 2008) Supported by NCRR K12 RR01761401, NHLBI K23 HL081492, and AADC P01 Al5050001.

Correspondence and requests for reprints should be addressed to Loren $\mathrm{C}$. Denlinger, M.D., Ph.D., Section of Allergy, Pulmonary, and Critical Care Medicine, University of Wisconsin School of Medicine and Public Health, 600 Highland Avenue, P.O. Box 9988, Madison, WI 53792. E-mail: Idenling@wisc.edu

This article has an online supplement, which is accessible from this issue's table of contents at www.atsjournals.org

Am J Respir Crit Care Med Vol 179. pp 265-270, 2009

Originally Published in Press as DOI: 10.1164/rccm.200802-2930C on November 21, 2008

Internet address: www.atsjournals.org

\section{AT A GLANCE COMMENTARY}

Scientific Knowledge on the Subject

$\mathrm{P}_{2} \mathrm{X}_{7}$ is a cation channel expressed by leukocytes and airway epithelial cells that is important to pathogen control and concomitant cellular inflammation. Its contribution to asthma pathophysiology has previously not been demonstrated.

What This Study Adds to the Field

Attenuated $\mathrm{P} 2 \mathrm{X}_{7}$ function is common in mild to moderate asthma, and is associated with decreased virus-induced nasal inflammation as well as an increased risk of an acute loss of symptom control.

asthma exacerbations, which has triggered an intense search for the risk factors that may synergize with this virus in susceptible individuals.

Abundant evidence supports the notion that the human gene $P 2 R X 7$ modulates the airway inflammatory response to infection in asthma. $P 2 R X 7$ is located in a region of chromosome $12 \mathrm{q} 24$ (15) known to contain multiple asthma genes linked to lung function and other biomarkers (16-18). It is expressed on respiratory epithelium and by most classes of leukocytes (1921). Bronchial challenge with allergens in humans and mice produces a lumenal release of extracellular ATP, the ligand for the $\mathrm{P} 2 \mathrm{X}_{7}$ receptor (22). Indirect evidence suggests that lumenal release of extracellular ATP also occurs in patients during naturally occurring viral infections of the lower airway (23). ATP in the airway serves as a biomarker for sputum neutrophilia in patients with cystic fibrosis (24). In transgenic animals, deletion of the murine $P 2 R X 7$ gene results in attenuation of compartmentalized, acute neutrophilic inflammation (25). The $\mathrm{P}_{2} \mathrm{X}_{7}$ receptor also regulates host cell clearance of intracellular pathogens, including the BCG and clinical strains of Mycobacterium tuberculosis in humans and cell culture as well as two species of Chlamydia in murine cells and animal models (26-29). In this fashion, $P 2 R X 7$ genetic variability may contribute to both the asthma phenotype as well as participant-specific differences in the potency of innate immune responses to airway pathogens.

The protein encoded by $P 2 R X 7$ assembles and functions as a homotrimeric, ligand-gated cation channel with a selectivity filter that reversibly dilates to a size restriction of approximately $900 \mathrm{D}$, a phenomenon referred to as "pore activity" $(30,31)$. We have previously described a genomically validated, functional screening assay in whole blood with the precision necessary for use as an epidemiologic tool $(32,33)$. Therefore, we hypothesized that $\mathrm{P} 2 \mathrm{X}_{7}$ pore function correlates with the neutrophilic airway response to an upper respiratory tract infection and can modify the subsequent risk of loss of asthma control. A poster 
abstract discussing a portion of this work has been published previously (34).

\section{METHODS}

All investigations were approved by the Human Subjects Committee of the University of Wisconsin (Madison, WI) Health Sciences Institutional Review Board, with written, informed consent and in accordance with the revised Declaration of Helsinki. Participants with allergic asthma were recruited as described in the online supplement.

\section{P2RX7 Genotyping and Validation of the Whole Blood Pore Assay}

Citrate- and ethylenediaminetetraacetic acid-anticoagulated whole blood samples were collected for the pore assay and genotyping, respectively. Assay methods have been published (33); additional details may be found in the online supplement. Pore activity is reported as the fold change in $3^{\prime}$ - $O$-(4-benzoyl)benzoyl adenosine $5^{\prime}$-triphosphate (Bz-ATP)-stimulated YO-PRO-1 uptake relative to the buffer control. Using these methods, the present data demonstrate a day-today intraparticipant coefficient of variance of 0.11 , which is similar to the reproducibility observed with fluorescent particle-adjusted instrument settings and propidium iodide exclusion of nonviable cells (35). The presence or absence of rhinovirus in nasal lavage samples does not alter the day-to-day variability of this whole blood assay $(P=0.144)$.

Genotyping was performed by restriction fragment length polymorphism analysis of genomic DNA-derived polymerase chain reaction (PCR) products, as previously described (33). Table E1 (see the online supplement) shows the $P 2 R X 7$ genotypes, pore activity, and assay performance analysis for identification of the patients with asthma in this study with validated loss-of-function genotypes.

\section{Asthma Phenotype Evaluation during the Course of the Cold}

Table E2 outlines the study's outpatient visit structure. Cold symptoms were assessed four times per day via modified Jackson participant diaries (36). Table E3 shows the asthma symptom and peak flow diary template that was completed twice daily. Nasal lavage and induced sputum samples were collected at the specified visits (Table E2) and processed as described (37). A multiplex PCR method able to detect more than 100 respiratory viruses (MultiCode-PLx respiratory virus panel; EraGen Biosciences, Madison, WI) (38) was used to determine the presence of any virus in nasal lavage and sputum samples. Rhinovirus-positive samples underwent subsequent quantitative PCR analysis that amplifies a highly conserved region of the rhinoviral genome (38). Spirometry and methacholine challenges were performed according to American Thoracic Society (New York, NY) guidelines. Loss of asthma control was defined by combining measures of asthma symptoms, medication use, and change in lung function to define a categorical variable described in the online supplement.

\section{Statistical Analysis}

All analyses were performed with Excel (Office 2004, version 11.3.6; Microsoft, Redmond, WA) and JMP (version 7.0; SAS Institute, Cary, NC) software. The ranked Spearman correlation coefficient was calculated for associations with clinical and biomarker data. The visits associated with peak neutrophil counts in the upper and lower airways were highly variable in this naturally acquired cold protocol. Because preinfection neutrophil counts were not available, we calculated the change in cell numbers as the peak minus the convalescent values for airway neutrophil counts. Normal distributions of the raw or transformed datasets were confirmed with the Shapiro-Wilk goodness of fit test. Regression analysis of asthma symptoms and the loss of control is described in the online supplement. For all tests, the significance level of $P<0.05$ was adopted.

\section{RESULTS}

\section{Participant Characteristics during the Cold and at Baseline}

Fifty-six participants with a self-identified cold were screened, 35 were enrolled, and 31 completed all of the acute and convales- cent baseline visits. Thirty-one patients consented to genetic analysis and 28 of these had complete visit data. The study participants had mild-to-moderate allergic asthma: 30 patients were using albuterol only as needed on entry, whereas 5 were already taking inhaled corticosteroids (ICSs) before the start of the cold (Table 1). All participants had an elevated modified Jackson cold survey symptom score on enrollment that decreased significantly at the recovery visits $(17.8 \pm 5.9$ vs. $2.6 \pm$ 3.6; $P<0.001)$. Twenty-two participants had a respiratory virus detected in nasal lavage fluid, and 18 of these were rhinoviruses. Thirty participants exhibited serologic documentation of prior exposure (positive $\mathrm{IgG}$ or $\mathrm{IgA}$ ) to either Chlamydia pneumoniae or Mycoplasma pneumoniae. None had a convincing pattern of acute infection (i.e., positive $\operatorname{IgM}$, rising $\operatorname{IgG}$ titer) by these atypical bacteria.

All participants had higher peak asthma symptom scores during the cold than at recovery $(7.7 \pm 5.3$ vs. $0.5 \pm 1.4 ; P<$ 0.001 ), and the peak asthma symptoms lagged peak cold symptoms by an average of 2 days. The peak cold symptom score correlated significantly with the change in asthma symptoms $\left(R_{\mathrm{s}}=0.458, P=0.014\right)$. In addition, the changes in either the cold or the asthma symptoms scores (i.e., acute minus recovery scores) correlated inversely with the change in daily peak flow recordings $\left(R_{\mathrm{s}}=-0.554\right.$ and $-0.494, P=0.003$ and 0.004 , respectively), such that higher symptoms corresponded to a greater decline in lung function. $\mathrm{FEV}_{1}$ values were not different between the acute and convalescent baseline visits. There was heightened methacholine responsiveness during the acute cold compared with convalescent values [mean $\log \left(\mathrm{PC}_{20}\right), 0.050$ vs. $0.571, P=$ 0.031], and the lowest $\mathrm{PC}_{20}$ occurred a median of one visit before the peak in asthma symptoms. There was a trend toward a lower $\mathrm{PC}_{20}$ during the acute cold in rhinovirus-positive participants $(P=0.099)$. Fifteen participants experienced loss of control with a substantial increase in asthma symptoms during the cold, and 4 of these individuals had either a severe decline in peak expiratory flow (PEF) or an increase in rescue therapy.

\section{Clinical Correlations with Nasal Lavage Neutrophils during the Cold}

An inverse relationship was observed between the change in nasal lavage neutrophils and the change in asthma symptoms (Figure 1A) with a positive correlation seen between the change in nasal lavage neutrophils and the difference in peak expiratory

TABLE 1. ASTHMA SEVERITY AND SYMPTOM SCORES AT ACUTE AND BASELINE VISITS

\begin{tabular}{lcc}
\hline & Acute Cold & $\begin{array}{c}\text { Cold Resolution, } \\
\text { Convalescent Baseline }\end{array}$ \\
\hline Peak cold symptom score & $17.8 \pm 5.9$ & $2.6 \pm 3.6$ \\
Peak asthma symptom score & $7.7 \pm 5.3$ & $0.5 \pm 1.4$ \\
$\mathrm{FEV}_{1}, \%$ predicted: mean $\pm \mathrm{SD}$ & $89.2 \pm 13.3$ & $95.9 \pm 12.1$ \\
${\text { Methacholine } \mathrm{PC}_{20}, \mathrm{mg} / \mathrm{ml}:}_{\quad}$ & $1.1(0.4,2.5)$ & $1.3(0.6,5.5)$ \\
$\quad$ median (IQR) & 22 participants, & Not determined \\
$\begin{array}{l}\text { Virus detection } \\
\text { Chlamydia pneumoniael }\end{array}$ & 18 with RV & \\
$\quad$ Mycoplasma pneumoniae & participants with & 30 participants with \\
serology & acute profile & prior exposure \\
\hline
\end{tabular}

Definition of abbreviations: IQR = interquartile range; methacholine $\mathrm{PC}_{20}=$ provocative concentration of methacholine causing a $20 \%$ fall in $\mathrm{FEV}_{1}$; RV = rhinovirus.

Thirty-five participants were enrolled and 32 completed all visits. The median and interquartile range of the age distribution was $20(18,23)$ years. Seventeen of 35 participants were male. The lowest acute values of $\mathrm{FEV}_{1} \%$ predicted and methacholine $\mathrm{PC}_{20}$ are reported from participants with paired values at the convalescent baseline. 
A
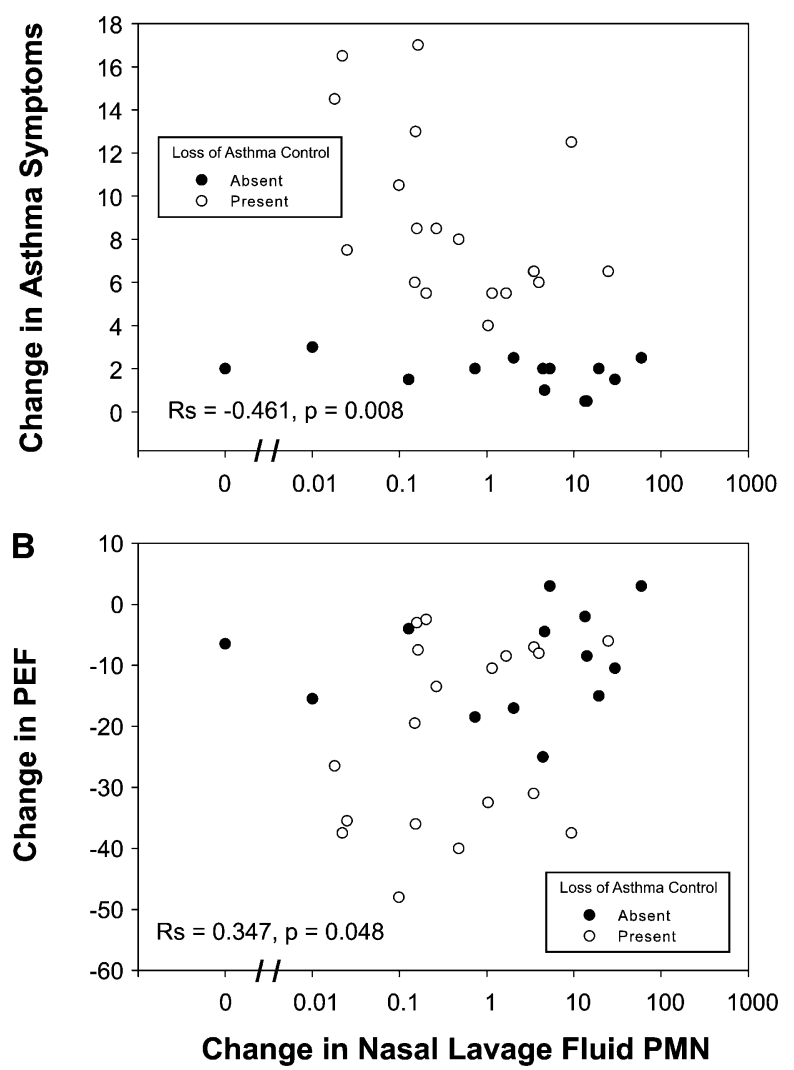

Figure 1. Nasal neutrophilia correlations to changes in symptoms or lung function. The change in cold or asthma symptoms, as well as the change in peak flow, during the course of a cold is plotted against the change in neutrophil counts in nasal lavage fluid. The presence or absence of a loss of asthma control during a cold is denoted by open circles and solid circles, respectively. Spearman correlation coefficients for the entire data set are shown. PEF = peak expiratory flow; PMN = polymorphonuclear neutrophils.

flow recordings (Figure 1B). These correlations were also apparent when evaluating the peak nasal lavage neutrophil counts $\left(R_{\mathrm{s}}=-0.593\right.$ and $0.397, P<0.001$ and $P=0.022$, respectively). In this sample with naturally acquired colds, neither the peak nor the change in sputum neutrophils correlates with differences in cold symptoms, asthma symptoms, or peak flow recordings $(P>0.1)$. Thus, markers of inflammation in the upper versus lower airway were more closely related to clinical cold indicators.

\section{P2X 7 Pore Function Correlations with Nasal Inflammation and Asthma Symptoms}

Because attenuation of $\mathrm{P} 2 \mathrm{X}_{7}$ function alters neutrophil accumulation to compartmentalized areas of inflammation in animal models (25), we evaluated this relationship during the upper and lower airway inflammatory response to naturally occurring viral infection. In this regard, we observed a correlation between $\mathrm{P} 2 \mathrm{X}_{7}$ pore activity and the change or the peak in nasal lavage neutrophil counts (Figure 2A). To test for a link between $\mathrm{P}_{2} \mathrm{X}_{7}$ function and rhinovirus shedding, a subset analysis was performed to quantify rhinovirus RNA in nasal lavage and sputum samples testing positive for this virus; 15 participants had sufficient material for this analysis. $\mathrm{P} 2 \mathrm{X}_{7}$ function was not related to viral shedding in either compartment $(P>0.1)$.

An inverse relationship was noted between $\mathrm{P} 2 \mathrm{X}_{7}$ function and the change in asthma symptoms (Figure 2B). Univariate
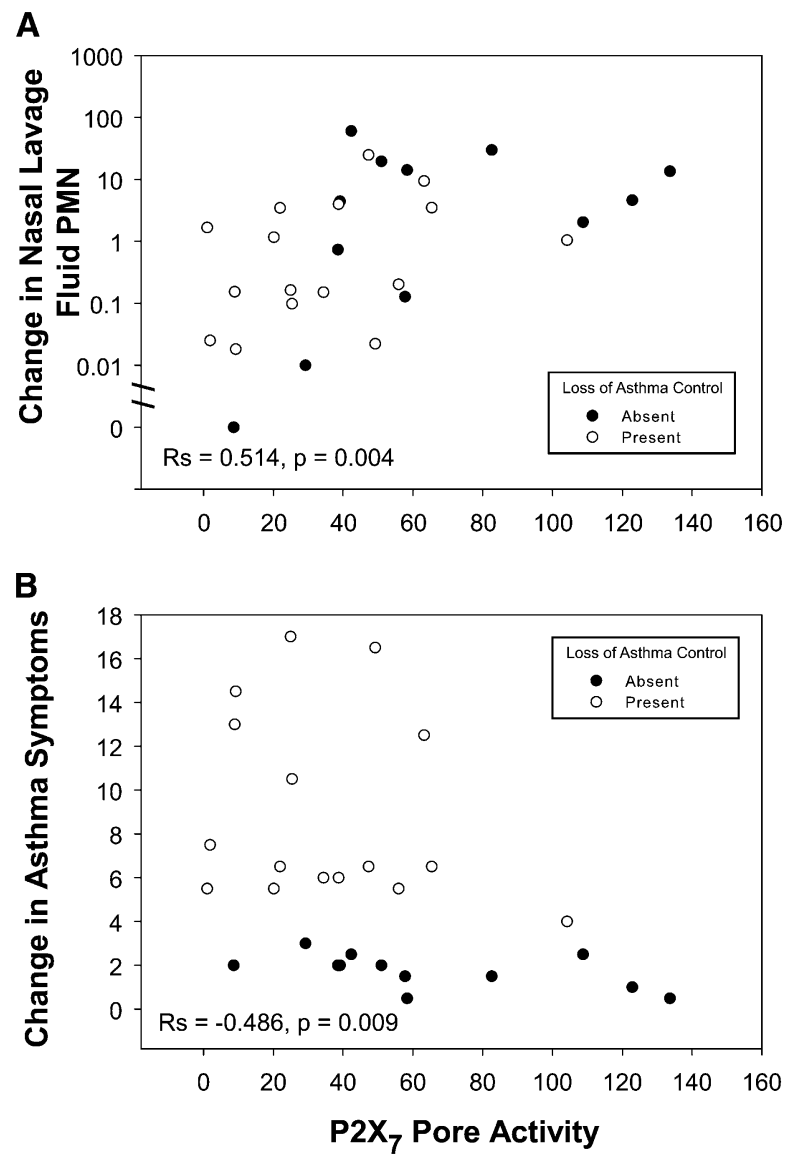

Figure 2. Change in nasal neutrophil count and asthma symptoms during a cold compared with $\mathrm{P} 2 \mathrm{X}_{7}$ pore function. Baseline nasal lavage neutrophil counts and asthma symptoms were subtracted from the peak levels, respectively, to depict the corresponding changes in cold symptoms. Data are plotted against $\mathrm{P} 2 \mathrm{X}_{7}$ pore function assessed in whole blood samples by the fold change in agonist-induced dye uptake. The presence or absence of a loss of asthma control during a cold is denoted by open symbols and solid symbols, respectively. Spearman correlation coefficients for the entire data set are shown.

predictors of the change in asthma symptoms during a cold included the change in PEF, the peak of cold symptoms, the peak of nasal lavage neutrophil counts, the precold use of ICSs, and the $\mathrm{P}_{2} \mathrm{X}_{7}$ pore activity (Table 2). Multivariate regression analysis of these factors demonstrates that the change in PEF, the precold use of inhaled corticosteroids, and $\mathrm{P}_{2} \mathrm{X}_{7}$ pore activity are the best predictors of asthma symptoms in this study with adjustment for the presence of rhinovirus (Table 3 ). $\mathrm{P}^{2} \mathrm{X}_{7}$ function was not associated with changes in peak expiratory flow $(P>0.1)$.

To begin to assess whether $\mathrm{P} 2 \mathrm{X}_{7}$ pore function relates to the risk of virus-induced loss of asthma control, we performed logistic regression with receiver-operator analysis shown in Figure 3. This model was adjusted for the presence of rhinovirus detection as well as precold use of ICS, and exhibited an area under the curve of $0.797(P=0.020)$. The performance characteristics at the optimal threshold of this adjusted model are as follows: sensitivity, 0.75; specificity, 0.75; positive predictive value, 0.857 ; negative predictive value, 0.714 . Moreover, the crude odds ratio associating low pore activity with the risk of developing an asthma exacerbation during the cold was 11.0 (95\% confidence interval: $1.1,106.4)$ and adjustment for the presence of rhinovirus and use of ICS raises the odds ratio to 15.0. 
TABLE 2. UNIVARIATE FACTORS ASSOCIATED WITH CHANGE IN ASTHMA SYMPTOMS DURING THE COLD

\begin{tabular}{lr}
\hline Factor & $P$ Value \\
\hline Change in peak expiratory flow & 0.002 \\
Baseline $\mathrm{FEV}_{1}, \%$ predicted & 0.796 \\
Baseline methacholine $\mathrm{PC}_{20}$ & 0.772 \\
Rhinovirus detection, yes/no & 0.149 \\
Peak cold symptoms & 0.010 \\
Change in cold symptoms & 0.095 \\
Precold ICS use & 0.005 \\
Peak nasal lavage neutrophils & 0.001 \\
Change in nasal lavage neutrophils & 0.019 \\
Peak sputum neutrophils & 0.337 \\
Change in sputum neutrophils & 0.160 \\
P2X & 0.012 \\
\hline
\end{tabular}

Definition of abbreviations: ICS = inhaled corticosteroids; methacholine $\mathrm{PC}_{20}=$ provocative concentration of methacholine causing a $20 \%$ fall in $\mathrm{FEV}_{1}$.

Univariate analysis by the least-squares or logistic method was applied for the preceding factors after data transformation to the normal distribution.

\section{DISCUSSION}

The present investigation is the first to report altered $\mathrm{P} 2 \mathrm{X}_{7}$ function in asthma. As a genomically validated diagnostic test, the whole blood $\mathrm{P} 2 \mathrm{X}_{7}$ pore assay serves as a useful epidemiologic tool by providing a continuous measure of protein function and thereby enhancing statistical power for clinical association. We demonstrate that $\mathrm{P} 2 \mathrm{X}_{7}$ pore activity is associated with a change in nasal lavage neutrophil counts during a cold and is inversely related to the development of asthma symptoms (Figure 2). Coupled with a change in peak expiratory flow recordings, $\mathrm{P} 2 \mathrm{X}_{7}$ pore function contributes to multivariate prediction of asthma symptoms (Table 3). With an area under the curve of 0.797 , receiver-operator curve analysis suggests that baseline assessment of $\mathrm{P} 2 \mathrm{X}_{7}$ pore activity is a useful marker to detect the risk of losing asthma control during a naturally acquired cold (Figure 3). In this model, individuals with normal pore function are predicted to have greater acute inflammation in the nose during the cold with a lower risk of asthma symptoms. Conversely, those with attenuated $\mathrm{P} 2 \mathrm{X}_{7}$ pore activity have lower nasal lavage neutrophils and a greater risk of loss of asthma control.

We and others have previously shown that neutrophil counts are elevated in nasal lavage fluid during an upper respiratory tract infection, but whether this is beneficial or injurious has not been fully delineated (5-9). In the present study, we show that the

TABLE 3. MULTIVARIATE REGRESSION MODELING OF CHANGE IN ASTHMA SYMPTOMS DURING THE COLD

\begin{tabular}{|c|c|c|c|}
\hline Term & $\begin{array}{c}\text { Estimate }(95 \% \\
\text { Confidence Interval) }\end{array}$ & Chi Square & $P$ Value \\
\hline Intercept & $3.154(2.378,3.929)$ & 34.5 & $<0.001$ \\
\hline Change in PEF & $-0.032(-0.049,-0.015)$ & 11.5 & 0.001 \\
\hline $\mathrm{P} 2 \mathrm{X}_{7}$ pore activity & $-0.141(-0.228,-0.054)$ & 9.1 & 0.003 \\
\hline Precold ICS use & $-0.741(-1.113,-0.369)$ & 12.9 & $<0.001$ \\
\hline $\mathrm{RV}$ detection & $-0.070(-0.313,0.172)$ & 0.3 & 0.558 \\
\hline
\end{tabular}

Definition of abbreviations: ICS = inhaled corticosteroids; PEF = peak expiratory flow; $\mathrm{RV}=$ rhinovirus.

As in Table 2, variables were transformed to fit the normal distribution. A preliminary multivariate model with all the significant univariate variables was built by the stepwise method by sequentially entering factors with the next highest F-statistic until the statistical power was depleted. Rhinovirus detection was not significant in the stepwise model, but was included subsequently because of its reported link to acute asthma symptoms. A generalized linear model was then used to calculate coefficient estimates, confidence intervals, and corresponding statistics. A residual plot of this generalized linear model has a random distribution.

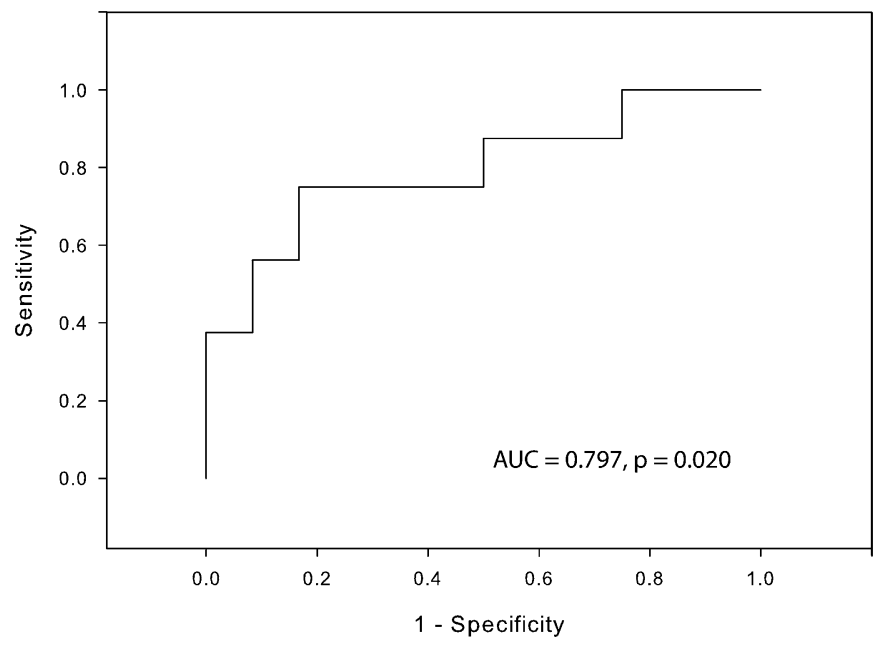

Figure 3. Use of the $\mathrm{P} 2 \mathrm{X}_{7}$ pore assay to predict loss of asthma control during a cold. Loss of asthma control was scored binomially on the basis of changes in medication use, symptom scores, and changes in lung function (see MetHODS). A receiver-operator curve plotting the performance characteristics of the $\mathrm{P} 2 \mathrm{X}_{7}$ pore assay was used in logistic regression analysis to predict the likelihood of the loss of asthma control. Adjustment for the precold use of inhaled corticosteroids (ICS) and the detection of rhinovirus was included in the model. These data are displayed in Table E4 (see the online supplement). AUC = area under the curve.

change in nasal lavage neutrophil count is related to the worsening of asthma symptoms and peak expiratory flow recordings (Figure 1). Infected nasal epithelial cells release chemokines to attract neutrophils $(37,39)$, but whether recruitment of this inflammatory cell population serves to limit viral spread, particularly to the lower airway, is unclear. Others have shown that nasal lavage $T$ cell subsets decline in some participants during a viral infection and that the magnitude of this decline correlates with the severity of the cold (40), and it is possible that neutrophils in this study are a preface to subsequent recruitment of chronic inflammatory cells with virus-directed cytotoxic activity. A notable difference between the present work and that of others $(1,2,5-9)$ is that sputum neutrophil counts did not correlate with development of asthma symptoms or a decline in PEF. This may be due to variable timing of respiratory sampling relative to the acquisition of the cold virus, a milder spectrum of baseline lung function, and/or viral strain differences.

Although $\mathrm{P}_{2} \mathrm{X}_{7}$ function has been reported in association with compartmentalized neutrophilic inflammation (25), the mechanisms by which this occurs in viral airway infection warrant further investigation. Notably, $\mathrm{P} 2 \mathrm{X}_{7}$ pore function was associated with lower symptoms but not lower amounts of viral RNA. This finding suggests two potential explanations. First, it is possible that the sample size was not adequately powered to find relationships with viral shedding, especially given the noise in the assay due to uncertain dilution factors associated with sampling of airway secretions. Second, it is possible that the $\mathrm{P}_{2} \mathrm{X}_{7}$ pore activity contributes to an initial influx of neutrophils, followed by a more efficient resolution of airway inflammation. In this regard, monocytic lineage cells including alveolar macrophages and dendritic cells (DCs) have the highest levels of cell surface expression of $\mathrm{P} 2 \mathrm{X}_{7}$ (41-43), and thus it is likely that the whole blood pore assay results reflect the function of airway macrophages and DCs. In animal models, DCs have an important role in controlling viral respiratory infection (44), and this hypothesis is testable in humans. Neutrophils also express this receptor, which 
has been reported to influence cell membrane fluidity (45), and thus a third possibility is that neutrophils and other inflammatory with attenuated pore function have reduced capacity for extravasation. Moreover, we have previously shown that individuals with attenuated pore function produce higher levels of IL-10 in response to inflammatory stimuli (32), and this cytokine has been independently associated with the risk of virus-induced asthma exacerbation (46). In summary, the present work predicts a model for future investigation wherein acute nasal inflammation may limit viral spread during a cold to the lower airway and protect against the loss of asthma control. This process may be further regulated by variable leukocyte and/or epithelial cell $\mathrm{P} 2 \mathrm{X}_{7}$ function.

A limitation of this study is that the small sample size precludes meaningful analysis of the contributions of viral serotype to quantitative viral burden or asthma symptoms. As well, the recruited participants generally had mild to moderate persistent asthma, and there were relatively few severe exacerbations. Nonetheless, our prospective design, extent of participant characterization, and frequency of study visits are significant strengths. Furthermore, the assay used to assess $\mathrm{P}_{2} \mathrm{X}_{7}$ pore function has low day-to-day variability, and robustly identifies samples with loss-of-function genotypes. Our data provide evidence that attenuated $\mathrm{P} 2 \mathrm{X}_{7}$ activity represents a risk factor for the loss of asthma control during a viral infection, and this hypothesis warrants additional testing in larger clinical studies. Future work is also needed to determine whether genotypes of $P 2 R X 7$ associated with loss of function interact with exposure to viral and/or atypical airway pathogens in early life to promote the inception and/or the severity of asthma.

Conflict of Interest Statement: L.C.D. does not have a financial relationship with a commercial entity that has an interest in the subject of this manuscript. L.S. does not have a financial relationship with a commercial entity that has an interest in the subject of this manuscript. A.G. does not have a financial relationship with a commercial entity that has an interest in the subject of this manuscript. K.S. does not have a financial relationship with a commercial entity that has an interest in the subject of this manuscript. D.G. does not have a financial relationship with a commercial entity that has an interest in the subject of this manuscript. A.M. does not have a financial relationship with a commercial entity that has an interest in the subject of this manuscript. K.H. does not have a financial relationship with a commercial entity that has an interest in the subject of this manuscript. R.L.S. does not have a financial relationship with a commercial entity that has an interest in the subject of this manuscript. W.W.B. has provided consultancy/advisory board services for Isis (2006-2008), Altana (2006-2007), Hoffman-LaRoche (2006), Ception (2006), Amgen (2006-2008), Centocor (2006-2008), Alza (2006), GlaxoSmithKline (2006-2008), Johnson \& Johnson (2006-2007), Wyeth (2006-2008), Takeda (2006), CV Therapeutics (20062008), Genentech/Novartis (2006-2008), Dynavax (2007), Abbott Laboratories (2007-2008), Millennium (2007), MAP Pharmaceuticals (2007), Merck (20062008), Asthmatic (2007), AstraZeneca (2007-2008), Pfizer (2006-2008), MedImmune (2007), Memory Pharmaceuticals (2007), Altair (2007-2008), PDL BioPharma (2007-2008), Schering Corporation (2008), and TEVA (2008); has received lecture fees from Novartis (2007-2008), Merck, AstraZeneca (20062008), and GlaxoSmithKline (2006-2008); and has received industry-sponsored grants from Novartis (2006-2008), Centocor (2006-2008), GlaxoSmithKline (2006-2008), Medicinova (2006), Dynavax (2006), Wyeth (2006), Pfizer (2006), Dey (2006), Astellas (2006), Inflazyme (2006), Biowa (2006), and Ception Therapeutics (2008). J.E.G. does not have a financial relationship with a commercial entity that has an interest in the subject of this manuscript.

Acknowledgment: This work would not be possible without the concerted effort of Asthma Clinical Study Coordinators in Madison, especially Leann Feiter, Evelyn Falibene, Erin Billmeyer, and Mary Jo Jackson. The authors thank Cheri Swenson for expert assistance with protocol issues, Rose Vrtis and Wai-Ming Lee for help with the multicode virus detection, and Mike Evans for consultative statistical help to guide the analysis plan.

\section{References}

1. Johnston SL, Pattemore PK, Sanderson G, Smith S, Campbell MJ, Josephs LK, Cunningham A, Robinson BS, Myint SH, Ward ME, et al. The relationship between upper respiratory infections and hospital admissions for asthma: a time-trend analysis. Am J Respir Crit Care Med 1996;154:654-660.
2. Atmar RL, Guy E, Guntupalli KK, Zimmerman JL, Bandi VD, Baxter BD, Greenberg SB. Respiratory tract viral infections in inner-city asthmatic adults. Arch Intern Med 1998;158:2453-2459.

3. Jacoby DB. Virus-induced asthma attacks. JAMA 2002;287:755-761.

4. Singh AM, Moore PE, Gern JE, Lemanske RF Jr, Hartert TV. Bronchiolitis to asthma: a review and call for studies of gene-virus interactions in asthma causation. Am J Respir Crit Care Med 2007; 175:108-119.

5. Fraenkel DJ, Bardin PG, Sanderson G, Lampe F, Johnston SL, Holgate ST. Lower airways inflammation during rhinovirus colds in normal and in asthmatic subjects. Am J Respir Crit Care Med 1995;151:879886.

6. Gern JE, Calhoun W, Swenson C, Shen G, Busse WW. Rhinovirus infection preferentially increases lower airway responsiveness in allergic subjects. Am J Respir Crit Care Med 1997;155:1872-1876.

7. Fleming HE, Little FF, Schnurr D, Avila PC, Wong H, Liu J, Yagi S, Boushey HA. Rhinovirus-16 colds in healthy and in asthmatic subjects: similar changes in upper and lower airways. Am J Respir Crit Care Med 1999;160:100-108.

8. Jarjour NN, Gern JE, Kelly EA, Swenson CA, Dick CR, Busse WW. The effect of an experimental rhinovirus 16 infection on bronchial lavage neutrophils. J Allergy Clin Immunol 2000;105:1169-1177.

9. Bardin PG, Fraenkel DJ, Sanderson G, van Schalkwyk EM, Holgate ST, Johnston SL. Peak expiratory flow changes during experimental rhinovirus infection. Eur Respir J 2000;16:980-985.

10. Pizzichini MM, Pizzichini E, Efthimiadis A, Chauhan AJ, Johnston SL, Hussack P, Mahony J, Dolovich J, Hargreave FE. Asthma and natural colds. Inflammatory indices in induced sputum: a feasibility study. Am J Respir Crit Care Med 1998;158:1178-1184.

11. Hoebee B, Bont L, Rietveld E, van Oosten M, Hodemaekers HM, Nagelkerke NJ, Neijens HJ, Kimpen JL, Kimman TG. Influence of promoter variants of interleukin-10, interleukin- 9 , and tumor necrosis factor- $\alpha$ genes on respiratory syncytial virus bronchiolitis. $J$ Infect Dis 2004;189:239-247.

12. Hull J, Rowlands K, Lockhart E, Moore C, Sharland M, Kwiatkowski D. Variants of the chemokine receptor CCR5 are associated with severe bronchiolitis caused by respiratory syncytial virus. J Infect Dis 2003; 188:904-907.

13. Hull J, Thomson A, Kwiatkowski D. Association of respiratory syncytial virus bronchiolitis with the interleukin 8 gene region in UK families. Thorax 2000;55:1023-1027.

14. Lahti M, Lofgren J, Marttila R, Renko M, Klaavuniemi T, Haataja R, Ramet M, Hallman M. Surfactant protein D gene polymorphism associated with severe respiratory syncytial virus infection. Pediatr Res 2002;51:696-699.

15. Buell GN, Talabot F, Gos A, Lorenz J, Lai E, Morris MA, Antonarakis SE. Gene structure and chromosomal localization of the human P2X 7 receptor. Receptors Channels 1998;5:347-354.

16. Xu J, Postma DS, Howard TD, Koppelman GH, Zheng SL, Stine OC, Bleecker ER, Meyers DA. Major genes regulating total serum immunoglobulin E levels in families with asthma. Am J Hum Genet 2000;67:1163-1173.

17. Malerba G, Lauciello MC, Scherpbier T, Trabetti E, Galavotti R, Cusin V, Pescollderungg L, Zanoni G, Martinati LC, Boner AL, et al. Linkage analysis of chromosome 12 markers in Italian families with atopic asthmatic children. Am J Respir Crit Care Med 2000;162:1587-1590.

18. Raby BA, Silverman EK, Lazarus R, Lange C, Kwiatkowski DJ, Weiss ST. Chromosome 12q harbors multiple genetic loci related to asthma and asthma-related phenotypes. Hum Mol Genet 2003;12:1973-1979.

19. Khakh BS, North RA. P2X receptors as cell-surface ATP sensors in health and disease. Nature 2006;442:527-532.

20. Marino A, Rodrig Y, Metioui M, Lagneaux L, Alzola E, Fernandez M, Fogarty DJ, Matute C, Moran A, Dehaye JP. Regulation by P2 agonists of the intracellular calcium concentration in epithelial cells freshly isolated from rat trachea. Biochim Biophys Acta 1999;1439: 395-405.

21. Ma W, Korngreen A, Weil S, Cohen EB, Priel A, Kuzin L, Silberberg $\mathrm{SD}$. Pore properties and pharmacological features of the P2X receptor channel in airway ciliated cells. J Physiol 2006;571:503-517.

22. Idzko M, Hammad H, van Nimwegen M, Kool M, Willart MAM, Muskens F, Hoogsteden HC, Luttmann W, Ferrari D, Di Virgilio F, et al. Extracellular ATP triggers and maintains asthmatic airway inflammation by activating dendritic cells. Nat Med 2007;13:913-919.

23. Wark PA, Johnston SL, Moric I, Simpson JL, Hensley MJ, Gibson PG. Neutrophil degranulation and cell lysis is associated with clinical severity in virus-induced asthma. Eur Respir J 2002;19:68-75. 
24. Esther CR, Alexis NE, Clas ML, Lazarowski ER, Donaldson SH, Ribeiro CM, Moore CG, Davis SD, Boucher RC. Extracellular purines are biomorkers of neutrophilic airway inflammation. Eur Respir J 2008;31:949-956.

25. Labasi JM, Petrushova N, Donovan C, McCurdy S, Lira P, Payette MM, Brissette W, Wicks JR, Audoly L, Gabel CA. Absence of the P2X receptor alters leukocyte function and attenuates an inflammatory response. J Immunol 2002;168:6436-6445.

26. Li CM, Campbell SJ, Kumararatne DS, Bellamy R, Ruwende C, McAdam KP, Hill AV, Lammas DA. Association of a polymorphism in the $\mathrm{P}_{2} \mathrm{X}_{7}$ gene with tuberculosis in a Gambian population. J Infect Dis 2002;186:1458-1462.

27. Saunders BM, Fernando SL, Sluyter R, Britton WJ, Wiley JS. A loss-offunction polymorphism in the human $\mathrm{P}_{2} \mathrm{X}_{7}$ receptor abolishes ATPmediated killing of mycobacteria. J Immunol 2003;171:5442-5446.

28. Fernando SL, Saunders BM, Sluyter R, Skarratt KK, Goldberg H, Marks GB, Wiley JS, Britton WJ. A polymorphism in the $\mathrm{P}_{2} \mathrm{X}_{7}$ gene increases susceptibility to extrapulmonary tuberculosis. Am J Respir Crit Care Med 2007;175:360-366.

29. Coutinho-Silva R, Stahl L, Raymond MN, Jungas T, Verbeke P, Burnstock G, Darville T, Ojcius DM. Inhibition of chlamydial infectious activity due to $\mathrm{P} 2 \mathrm{X}_{7} \mathrm{R}$-dependent phospholipase D activation. Immunity 2003; 19:403-412.

30. Gudipaty L, Humphreys BD, Buell G, Dubyak GR. Regulation of P2X nucleotide receptor function in human monocytes by extracellular ions and receptor density. Am J Physiol Cell Physiol 2001;280:C943-C953.

31. Smart ML, Panchal RG, Bowser DN, Williams DA, Petrou S. Pore formation is not associated with macroscopic redistribution of $\mathrm{P}_{2} \mathrm{X}_{7}$ receptors. Am J Physiol Cell Physiol 2002;283:C77-C84.

32. Denlinger LC, Angelini G, Schell K, Green DN, Guadarrama AG, Prabhu U, Coursin DB, Bertics PJ, Hogan K. Detection of human $\mathrm{P}_{2} \mathrm{X}_{7}$ nucleotide receptor polymorphisms by a novel monocyte pore assay predictive of alterations in lipopolysaccharide-induced cytokine production. J Immunol 2005;174:4424-4431.

33. Denlinger LC, Coursin DB, Schell K, Angelini G, Green DN, Guadarrama AG, Halsey J, Prabhu U, Hogan KJ, Bertics PJ. Human P2X 7 pore function predicts allele linkage disequilibrium. Clin Chem 2006;52: 995-1004.

34. Denlinger L, Guadarrama A, Green D, Hogan K, Vrtis R, Lee W, Crisafi G, Morin A, Sorkness R, Busse W, et al. Regulation of asthmatic airway neutrophilia by $\mathrm{P}_{2} \mathrm{X}_{7}$ function during a cold [abstract]. Am J Respir Crit Care Med 2007;174:A474.

35. Korpi-Steiner NL, Sheerar D, Puffer EB, Urben C, Boyd J, Guadarrama A, Schell K, Denlinger LC. Standardized method to minimize variability in a functional $\mathrm{P} 2 \mathrm{X}_{7}$ flow cytometric assay for a multicenter clinical trial. Cytometry B Clin Cytom 2008;74B:319-329.

36. Jackson GG, Dowling HF, Spiesman IG, Bonand AV. Transmission of the common cold to volunteers under controlled conditions: the common cold as a clinical entity. Arch Intern Med 1958;101:267278.

37. Gern JE, Vrtis R, Grindle KA, Swenson C, Busse WW. Relationship of upper and lower airway cytokines to outcome of experimental rhinovirus infection. Am J Respir Crit Care Med 2000;162:2226-2231.

38. Lee WM, Grindle K, Pappas T, Marshall DJ, Moser MJ, Beaty EL, Shult PA, Prudent JR, Gern JE. High-throughput, sensitive, and accurate multiplex PCR-microsphere flow cytometry system for large-scale comprehensive detection of respiratory viruses. J Clin Microbiol 2007; 45:2626-2634.

39. Zhu Z, Gwaltney JM, Wu Y, Elias JA. Rhinovirus stimulation of interleukin-8 in vivo and in vitro: role of NF-кB. Am J Physiol 1997;273:L814-L824.

40. Levandowski RA, Ou DW, Jackson GG. Acute-phase decrease of T lymphocyte subsets in rhinovirus infection. J Infect Dis 1986;153:743748.

41. Gu BJ, Zhang WY, Bendall LJ, Chessell IP, Buell GN, Wiley JS. Expression of $\mathrm{P}_{2} \mathrm{X}_{7}$ purinoceptors on human lymphocytes and monocytes: evidence for nonfunctional $\mathrm{P} 2 \mathrm{X}_{7}$ receptors. Am J Physiol Cell Physiol 2000;279:C1189-C1197.

42. Mutini C, Falzoni S, Ferrari D, Chiozzi P, Morelli A, Baricordi OR, Collo G, Ricciardi-Castagnoli P, Di Virgilio F. Mouse dendritic cells express the $\mathrm{P}_{2} \mathrm{X}_{7}$ purinergic receptor: characterization and possible participation in antigen presentation. J Immunol 1999;163:1958-1965.

43. Lemaire I, Falzoni S, Leduc N, Zhang B, Pellegatti P, Adinolfi E, Chiozzi $\mathrm{P}$, Di Virgilio F. Involvement of the purinergic $\mathrm{P}_{2} \mathrm{X}_{7}$ receptor in the formation of multinucleated giant cells. J Immunol 2006;177: $7257-7265$.

44. Wang H, Perters N, Schwarze J. Plasmacytoid dendritic cells limit viral replication, pulmonary inflammation, and airway hyperresponsiveness in respiratory syncytial virus infection. J Immunol 2006;177:62636270.

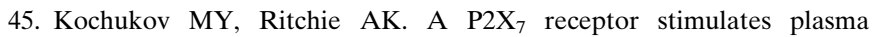
membrane trafficking in the FRTL rat thyrocyte cell line. Am J Physiol Cell Physiol 2004;287:C992-C1002.

46. Bont L, Heijnen CJ, Kavelaars A, van Aalderen WM, Brus F, Draaisma JT, Geelen SM, Kimpen JL. Monocyte IL-10 production during respiratory syncytial virus bronchiolitis is associated with recurrent wheezing in a one-year follow-up study. Am J Respir Crit Care Med 2000;161:1518-1523. 